\title{
Strategic Change and the Improvement of Organizational Performance：A Study Based On Meta-Analysis
}

\author{
Junjie $\mathbf{W u}^{1}$,Shanshan Wang ${ }^{2}$,Fan Yang ${ }^{2}$, Ying $\mathbf{L i}^{2}$ \\ ${ }^{1}$ School of Management, Zhejiang Shuren University, Zhejiang, Hangzhou, 310015, China \\ ${ }^{2}$ School of Economics and Management, Southwest University, Chongqing,400715 PR China
}

\begin{abstract}
Objectives: In order to explore the factors that lead to the difference of outcome between strategic change and organizational performance.Methods: This paper takes the correlation coefficient between strategic change and organizational performance as the effect value, and conducts Meta integration analysis and Meta regression analysis on 23 important literatures involving 7225 enterprise samples from 2008 to 2018. Results: Firstly, the meta-integration method is used to estimate the overall results of existing empirical studies. The results show that strategic change is significantly positively correlated with organizational performance. Second, there are too many moderating factors that lead to different conclusions of research on strategic change-organizational performance. Therefore, Meta regression method is used to explore the impact of 10 moderating factors on the relationship between the two. First, positive strategic change has a better moderating effect; Second, compared with small and medium-sized enterprises, the performance of strategic change of large-scale enterprises is better; Third, the more recent the year of publication, the less supportive the relationship between strategic change and organizational performance; Fourth, there is no significant difference between data types and the relationship between strategic change and organizational performance, but data time span has a significant negative moderating effect.Conclusions: This study shows that the quantitative literature study of meta analysis not only helps to resolve the existing theoretical disputes, but also helps to explore new theoretical studies in the context of COVID-19 epidemic in the future, meanwhile, it also provides a novel framework for quantitative literature analysis.
\end{abstract}

Keywords: Strategic change,organizational performance, meta-comprehension, meta-regression

\section{Introduction}

Since 2020, the COVID-19 epidemic has transformed production and people's lifestyles, in order to adapt to the changing external environment and gain or maintain competitive advantages, enterprises tend to implement strategic changes ${ }^{[1]}$. Gradually, the ability to make appropriate strategic change decisions quickly have become a potential competitive advantage of enterprises in the digital age crossing the background of globalization ${ }^{[2,3]}$.

Nokia led the traditional Mobile Communication Industry in the 2G era in the 1990s when Apple had yet to enter the mobile phone industry. In 2007, Apple entered in the market, Steve Jobs integrated Internet technology into mobile phone and redefined it, and thus the function of mobile phone changed greatly on the basis of communication. However, Nokia still focused on the traditional communication functions. Evidently, Apple has taken over the global smartphone market, while Nokia is nowhere near to Apple ${ }^{[4]}$. On the contrary, in the newly industrialized countries represented by China, some enterprises, such as Huawei, Haier and Alibaba, gained the growth advantage of sustainable competition through the sustained strategic change and the integration of resources. This contrast again warns theorists and entrepreneurs that organizational development is increasingly dependent on strategic change. Even Professor Burns of Manchester School of Management argues that organizational theory is the "Theory of Change" ${ }^{,[5]}$.

In short, Strategic change mainly has effects on organizational structure and culture by the influence of resource allocation mode, which later affects performance ${ }^{6}$. How strategic change affects organizational performance is a research hotspot in organizational management. Classical theories hold that strategic change has a positive impact on organizational performance ${ }^{7,8}$, but there are also contrary views that financial change will reduce financial performance ${ }^{9}$. At the same time, other studies suggest that there is a U-shaped relationship between strategic

ISSN: 0010-8189

(C) CONVERTER 2021

www.converter-magazine.info 
change and organizational performance ${ }^{10}$, or the relationship between them depends on the type of strategic change and the nature of the industry environment ${ }^{11}$.

In the complex environment of China's economic transformation, the impact of strategic change on organizational performance is more difficult to describe ${ }^{12}$. Traditional thoughts are difficult to fit in with complex realities and we require new theories and methods to guide the practice ${ }^{13}$. Meta-analysis methods can integrate existing studies to obtain the average effect value and explore factors which contribute to make research results different ${ }^{14}$. Therefore, this study adopts the Meta method to make up for the shortcomings of qualitative and quantitative literature research in this field. It also analyzes the causes of heterogeneity, the relationship between strategic change and organizational performance, and provide solutions to existing theoretical disputes. Besides, the explanatory power of the theory of strategic change on organizational performance has certain innovations in methods and theories.

\section{Literature Review and Established Assumptions}

2.1 The basic relationship between strategic change and organizational performance

Some studies have shown that strategic change has a positive correlation with organizational performance: Du Wei et al. empirically studied the relationship between knowledge management strategy and performance, and the results show that they are significantly positively correlated ${ }^{15}$; Li Wei's empirical results on 228 technology companies indicate market-oriented and technology-oriented strategic changes are significantly positively correlated with performance ${ }^{16}$. However, Liu Haijian believes that enterprises will implement specific practices and accumulate resources with strategic inertia. The competitive advantage of enterprises depends largely on these resources and practices ${ }^{17}$, but if breaking the inertia will bring shocks to organizations performance ${ }^{18}$. Other studies have shown that the cost of strategic change increases with the intensity of change. Moderate strategic change has a positive impact on performance. When the intensity of strategic change exceeds the limit, enterprises cannot effectively manage changes or make unfavorable changes. The two have an inverted U-shaped relationship ${ }^{19}$; At the same time, some studies have shown that enterprises have strategic inertia. The low degree of strategic change costs a lot of coordination costs, which will reduce performance. However, when the degree of strategic change exceeds the inertia, organizations can effectively allocate and better adapt to internal and external resources, which will improve performance. Conditions are conducive to improving performance, so there is a U-shaped relationship between strategic change and organizational performance ${ }^{20}$. But there are also studies showing that strategic change is not related to organizational performance ${ }^{21}$. The above quoted differences indicate that there is controversy in the field of strategic change and organizational performance. In this disputed area, Meta method is suitable for quantitative literature analysis.

Rational adaptation theory believes that organizations adapt to changing environments through strategic change so as to improve performance ${ }^{22}$. The contingency theory emphasizes that organization performance is determined by the adaptability to the structure and the environment, while strategic change promotes organizational structure to adapt better to internal and external environments, thus strategic change will improve organizational performance. However, the theory of resource dependence believes that organizations can acquire heterogeneous resources through strategic changes such as cooperation and diversification to reduce dependency on external resources, thereby enhancing their competitiveness and performance ${ }^{23}$. Enterprises make appropriate strategic changes with their own resources and capabilities in order to improve organizational characteristics, then adapt internal structures to the external environment. Combining these aspects will have a positive impact on organizational performance $^{24,25}$. Therefore, the following assumptions are made:

H1: The overall estimation of the relationship between strategic change and performance is a positive relationship.

2.2 Moderator affecting the relationship between strategic change and organizational performance

ISSN: 0010-8189

(C) CONVERTER 2021

www.converter-magazine.info 
In the research of strategic change-organizational performance relationship mechanism, the moderators that influence the relationship between independent variables and dependent variables are included in the analysis system, so the reasons for the differences in research results can be scientifically analyzed. By reading a large number of literature on strategic change and meta-analysis, it is known that there are four levels of moderators that influence the relationship between strategic change and organizational performance.

2.2.1 Moderators at the variable level

(1) Measurement of strategic change believe that the measurement of strategic change can consider the type of strategic change, the strength of strategic choice, and the strategic orientation ${ }^{26}$. For the measurement of strategic change, this paper studies from the two types of strategic change and the intensity of strategic change. Li Wei divided the corporate strategy into two orientations ${ }^{16}$. First, market orientation: customer orientation, competition orientation, cross-departmental coordination, and second, technology orientation: technological advancement and product flexibility. Chen (2002) and Xue and $\mathrm{Xu}$ (2001) divide the strategic change into a gradual and abrupt change from the perspective of the degree of strategic change of the enterprise ${ }^{27,28}$.

Based on the existing researches, this study uses market orientation and technology orientation to classify the types of strategic change, and divides the intensity of strategic change with two categories-positive and conservative, and comprehensively measures strategic change. Market-oriented offensive companies develop better, and positive strategic changes are beneficial to organizational performance ${ }^{29,30}$, so the following assumptions are made:

H2a: Market-oriented strategic changes are more likely to achieve good performance.

H2b: Positive strategic changes are easier to get good performance.

(2) Measurement of organizational performance. Organizational performance is mainly measured by two indicators: First, accounting indicators, Wang and $\mathrm{Mao}^{31}$ believe that the use of accounting indicators to measure performance has been criticized by many scholars, but the use of accounting indicators to measure performance is the most commonly used way in the field of strategic management ${ }^{32,33}$. Accounting indicators include total return on assets (ROA), return on equity (ROE), return on sales (ROS), earnings before interest and taxes (EBIT), earnings growth, sales growth rate, etc.; second, market indicators, including earnings per share (EPS), Tobin Q, etc.

In order to study the impact of strategic change on organizational performance, organizational performance is divided into long-term performance and short-term performance. Long-term performance indicators include Tobin Q, sales growth, profit growth, etc. Short-term performance indicators include total return on assets (ROA), return on equity (ROE), return on sales (ROS), earnings before interest and taxes (EBIT), etc. The company develops strategies to achieve long-term development goals, and strategies' impact on organizational performance may not be apparent in the short term ${ }^{34}$. Therefore, the following assumptions are made:

H2c: Strategic change has a better impact on long-term performance than short-term performance.

2.2.2 Moderators at the sample level

(1) Size of the company. Generally speaking, small and medium-sized enterprises have limited resources and capabilities due to their immature organizational system, while large enterprises have more resources and capabilities to respond more quickly to changes in internal and external environments. Therefore, the research hypothesis is proposed:

H3a: Large enterprises are more likely to achieve better performance than small and medium-sized enterprises on strategic changes.

ISSN: 0010-8189

(C) CONVERTER 2021 
(2) The nature of the enterprise. The internal environment and external environment faced by enterprises of different nature are different. The state-owned enterprises have strong bureaucratic culture and their ability to accept new things is not strong. The direction and intensity of strategic change are less different from historical strategies. In other words, other companies are more likely to make strategic changes in the general direction, and they can respond more flexibly to environmental changes, so their strategic changes may achieve better performance. Therefore, the research hypothesis is proposed:

H3b: Non-state-owned enterprises are more likely to achieve better performance than state-owned enterprises on strategic changes.

(3) The industry in which the company is located. Rapidly changing markets and technologies keep high-tech industries alert, they keep investing in technology, pay close attention to market dynamics and adjust accordingly. Traditional industries are located in relatively comfortable environment, and their ability to respond to external changes is not strong. . Therefore, the research hypothesis is proposed:

H3c: The strategic changes of high-tech industry enterprises are easier to achieve better performance than traditional industry enterprises on strategic changes.

(4) Whether the company is listed or not. Generally speaking, listed companies are listed to issue stocks after a strict audit. They are more resourceful and more capable than non-listed companies, so their strategic changes are more likely to be successful ${ }^{14}$. Therefore, the research hypothesis is proposed:

H3d: Compared to non-listed companies, listed companies are more likely to achieve better performance when they make strategic changes.

2.2.3 Moderators at the document level

(1) Journal impact factor. Journals with different influences have different orientations in their publications. Generally speaking, journals with greater influence pay more attention to the significance of research results ${ }^{14}$. Therefore, the following assumptions are made:

H4a: The greater the journal impact factor, the more likely it is to get better strategic change - organizational performance results.

(2) Year of publication of the document. In different years, literature publication has its own unique tendency. The financial crisis in 2008 has caused a major change for all enterprises. The impact of corporate strategic change on performance before and after the financial crisis is different. In the era of advocating change, journals tend to publish articles with significant positive effects of strategic change. Therefore, the following assumptions are made:

$\mathrm{H} 4 \mathrm{~b}$ : The closer an article is published, the more likely it is to get a positive relationship between strategic change and organizational performance.

2.2.4 Moderators at the design level

(1) Data type. There are various data processing methods in the literature, and the impact on the results is also different. Panel data can well overcome the non-dynamic, multicollinearity and other defects of cross-section data or time series data, and better reflect the relationship between variables ${ }^{14}$. Therefore, the research hypothesis is proposed:

H5a: Panel data is more likely to be positively related to strategic change and performance compared to other data types.

ISSN: 0010-8189 
(2) The time span of the data. The data refers to the measured performance value. The impact of strategic change on organizational performance may have a lag effect that can only be reflected by longer-term data analysis. Therefore, the research hypothesis is proposed:

H5b: The greater the time span of data, the more likely it is to get a positive correlation between strategic change and organizational performance.

\section{Research Design}

\subsection{Literature search and screening}

We collected the sample literature needed for this study by searching for the CNKI database with keywords such as "strategy", "strategic change", "organizational performance", "strategic change and organizational performance"; Besides, relevant and similar keywords are provided, as well as references in the literature, to increase the sample size.

After obtaining the initial literature, the screening is based on the following principles: the article studies the relationship between strategic change and organizational performance, the correlation coefficient between strategic change and organizational performance, or the value of the correlation coefficient, such as t value; the sample size is excluded from other literatures. If such large literature is included in the analysis, other literature weights are minimal, and meta-analysis is meaningless. According to the above principles, 23 documents were finally retained as samples, and they are shown in the attached table.

\subsection{Data encoding and meta regression analysis design}

3.2.1 Moderators at the variables and samples level

Measurement of strategic change: The type of strategic change in the sample literature belongs to the business level strategy is code 1 and type of strategic change that belongs to the company level strategy is code 0 . The intensity of strategic change: when the intensity of strategic change is positive is code 1 , conservative is code 0 ; measurement of organizational performance: the performance indicator used in the sample literature that belongs to the longterm indicator is code 1, otherwise code 0.Enterprise scale: Two dummy variables of "large-scale enterprise" and "small and medium-sized enterprise" is set and the mixed-scale enterprises are used as reference. When the sample enterprises are all large-scale enterprises, the "large-scale enterprise" code is 1 , otherwise it is 0 . When all are small and medium-sized enterprises, the "small and medium-sized enterprises" is code 1 , otherwise 0 ; the nature of the enterprise: the research sample in the literature that contains a variety of enterprise nature is code 1 , the research sample that contains all state-owned enterprises is code 0 ; the industry in which the enterprise is located: The two dummy variables of the traditional industry and the high-tech industry are based on the mixed industry standards. The sample companies all belong to the traditional industry are code 1 , otherwise they are 0 . All belong to the high-tech industry are code 1 , otherwise they are 0 ; whether the company is listed: listed company is code 1 , otherwise 0 .

\subsubsection{Moderators at the literature and research design level}

Journal influence: journal composite impact factors are used to represent journal influence. By reading a large number of literatures and web queries, it is found that the composite impact factor is more influential in 2 (including 2) journals. Therefore, when the composite impact factor of the journals in the sample literature is $\geq 2$ is code 1, otherwise 0 ; The year of publication: the year of publication after the 2009 is code 1 , otherwise 0 ; data type: the panel data in the sample literature is code 1 , otherwise 0 ; the data time span: when there is a lag period is code 1 , and the current data code is 0 .

3.3 Meta integration analysis design

ISSN: 0010-8189 
3.3.1 Determine the effect value

The correlation coefficient $r$ is easy to obtain and can well reflect the correlation between variables. Therefore, this paper takes the correlation coefficient $r$ of strategic change and organizational performance as the effect value statistic. In some articles, there are multiple correlation coefficients. If they belong to the same dimension, the average value is taken as the effect value. If they belong to different latitudes, they are included as effect values.

\subsubsection{Heterogeneity test and model selection}

The heterogeneity test is to illustrate the degree of deviation of each effect value from the overall estimated effect value. The $\mathrm{Q}$ test is the most common method of heterogeneity testing. The $\mathrm{Q}$ value significantly indicates that the effect value has a large heterogeneity, and the random effect model should be selected; if the $Q$ value is not significant, the random effect model or the fixed effect model can be used.

\section{Meta Integrated Analysis and Meta Regression Analysis Results}

\subsection{The value of each literature effect and the ratio of literature weight}

The effect values and weights of the 23 literatures are shown in the table. The effect value is obtained after the correlation coefficient or correlation coefficient is averaged or converted. If there are multiple effect values included in the analysis, the literature weight is the sum of the multiple effect value weights.

Since there is a "drawer effect" in the literature publishing process, i.e. the results of published literature are generally highly significant. It is possible that the results of the paper in the "drawer" are very different from the published literature, that is, there is "publishing bias", which will cause the estimate of this article bias. Meta can scientifically test and correct the "publish bias."

Funnel Plot of Standard Error by Fisher's Z

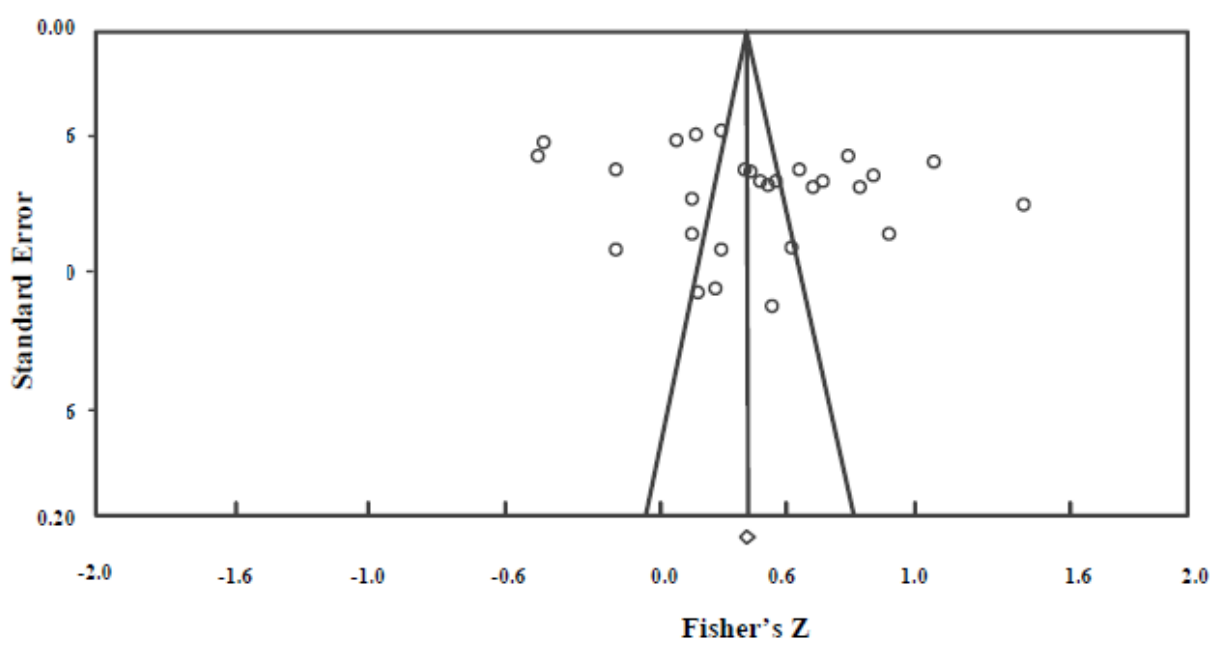

Fig1: Funnel chart 


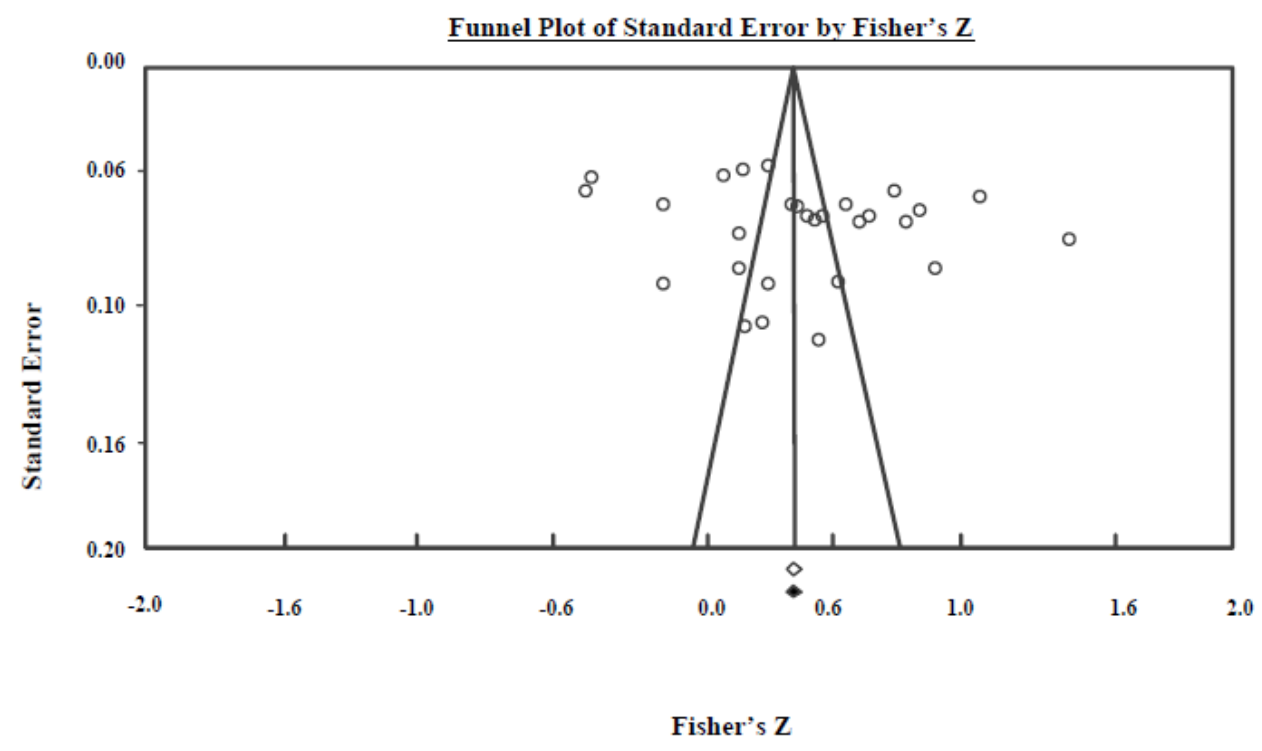

Fig2: Publication bias test

From Figure 1 and Figure 2, most of the sample literature is concentrated in the upper middle part of the funnel chart, indicating that the quality of the literature passed. The points in the funnel chart are the estimated symmetrical distribution around the true point, and the black diamond representing the published bias corrected effect value is on the same vertical line as the white diamond representing the uncorrected effect value, indicating that there is no publish bias in this study.

\subsection{Meta integrated analysis results}

Table 1 is the result of Meta's consolidated analysis. The value Q is significant, it means that the study exists heterogeneity (Q-943.085, P 0.001). The value of I2 in Table 1 is $96.925 \%$, which shows that heterogeneity accounts for $96.925 \%$ of the total variation of the effect value, further verifying heterogeneity. This shows that the random effect model should be used in this study, and Meta regression should be carried out to find the heterogeneous causes. The average effect value in the random effect model is 0.340 (Z-5.189, P-0.000), which means that the overall estimated value of the relationship between strategic change and organizational performance is 0.328 ; The confidence interval of $95 \%$ of the average effect value does not include 0 and the lower limit is greater than 0 , indicating that the correlation coefficient is significantly greater than 0 , that is, strategic change is significantly positively correlated with organizational performance in general, which also supports the hypothesis H1

Table 1 Average effect value and heterogeneity test results

\begin{tabular}{|c|c|c|c|c|c|c|c|c|}
\hline \multirow[t]{2}{*}{ Model } & \multirow{2}{*}{$\begin{array}{l}\text { Average } \\
\text { effect } \\
\text { value }\end{array}$} & \multicolumn{2}{|c|}{$95 \%$ confidence interval } & \multirow[b]{2}{*}{$\mathrm{Z}$} & \multirow[b]{2}{*}{$\mathrm{P}$} & \multirow[b]{2}{*}{ Q } & \multirow[b]{2}{*}{$\operatorname{Df}(Q)$} & \multirow[b]{2}{*}{$\mathrm{I}^{2}$} \\
\hline & & $\begin{array}{l}\text { Lower } \\
\text { bound }\end{array}$ & $\begin{array}{l}\text { Upper } \\
\text { bound }\end{array}$ & & & & & \\
\hline $\begin{array}{l}\text { Fixed } \\
\text { effect }\end{array}$ & 0.324 & 0.303 & 0.345 & 28.387 & 0.000 & 943.085 & 29 & $96.925 \%$ \\
\hline
\end{tabular}




\begin{tabular}{|l|l|l|l|l|l|l|l|l|}
\hline $\begin{array}{l}\text { Random } \\
\text { effects }\end{array}$ & 0.340 & 0.217 & 0.452 & 5.189 & 0.000 & & & \\
& & & & & & & & \\
\hline
\end{tabular}

4.3 Meta regression analysis results

Meta regression is applied to explore the impact of 4 sets of regulatory factors on strategic change-performance relationship. Models 1-4 in Table 2 examine the role of variable level, sample level, literature level and research design level respectively on the adjustment of strategic change-organizational performance relationship, and model 5 is the full variable model.

Table 2 Meta regression analysis results on factors affecting strategic change-organizational performance relationship adjustment

\begin{tabular}{|c|c|c|c|c|c|c|}
\hline & $\begin{array}{l}\text { Regulatory } \\
\text { factors }\end{array}$ & Model 1 & Model 2 & Model 3 & Model 4 & Model 5 \\
\hline \multirow{3}{*}{$\begin{array}{l}\text { Variable } \\
\text { level }\end{array}$} & $\begin{array}{l}\text { Types of } \\
\text { strategic change }\end{array}$ & $\begin{array}{l}-0.111 \\
(0.104)\end{array}$ & & & & $\begin{array}{l}0.030 \\
(0.075)\end{array}$ \\
\hline & $\begin{array}{l}\text { The intensity of } \\
\text { strategic change }\end{array}$ & $\begin{array}{l}0.002 \\
(0.098)\end{array}$ & & & & $\begin{array}{l}0.158^{* *} \\
(0.075)\end{array}$ \\
\hline & $\begin{array}{l}\text { Organizational } \\
\text { performance } \\
\text { measurement }\end{array}$ & $\begin{array}{l}0.091 \\
(0.039)\end{array}$ & & & & $\begin{array}{l}0.104 \\
(0.154)\end{array}$ \\
\hline \multirow{6}{*}{ Sample level } & $\begin{array}{l}\text { Large-scale } \\
\text { enterprises }\end{array}$ & & $\begin{array}{l}0.203 \\
(0.044)\end{array}$ & & & $\begin{array}{l}0.389^{* *} \\
(0.095)\end{array}$ \\
\hline & $\begin{array}{l}\text { Small-scale } \\
\text { enterprises }\end{array}$ & & $\begin{array}{l}0.028 \\
(0.134)\end{array}$ & & & $\begin{array}{l}0.123 \\
(0.024)\end{array}$ \\
\hline & $\begin{array}{l}\text { High-tech } \\
\text { industries }\end{array}$ & & $\begin{array}{l}0.254^{*} \\
(0.031)\end{array}$ & & & $\begin{array}{l}0.209^{* *} \\
(0.030)\end{array}$ \\
\hline & $\begin{array}{l}\text { Traditional } \\
\text { industries }\end{array}$ & & $\begin{array}{l}-0.279^{* *} \\
(0.091)\end{array}$ & & & $\begin{array}{l}-0.103 \\
(0.098)\end{array}$ \\
\hline & $\begin{array}{l}\text { Listed } \\
\text { companies }\end{array}$ & & $\begin{array}{l}-0.157 \\
(0.008)\end{array}$ & & & $\begin{array}{l}0.213^{* *} \\
(0.013)\end{array}$ \\
\hline & $\begin{array}{l}\text { Mixed } \\
\text { ownership }\end{array}$ & & $\begin{array}{l}0.371^{*} \\
(0.094)\end{array}$ & & & $\begin{array}{l}0.557^{* * *} \\
(0.057)\end{array}$ \\
\hline \multirow{2}{*}{$\begin{array}{l}\text { Literature } \\
\text { Level }\end{array}$} & $\begin{array}{l}\text { Journal } \\
\text { Influence } \\
\text { Factors }\end{array}$ & & & $\begin{array}{l}-0.089 \\
(0.105)\end{array}$ & & $\begin{array}{l}-0.143 \\
(0.122)\end{array}$ \\
\hline & $\begin{array}{ll}\text { Year } & \text { of } \\
\text { publication } & \text { of } \\
\text { the literature } & \end{array}$ & & & $\begin{array}{l}-0.256^{* *} \\
(0.014)\end{array}$ & & $\begin{array}{l}-0.035 \\
(0.106)\end{array}$ \\
\hline $\begin{array}{l}\text { Research } \\
\text { design level }\end{array}$ & Data type & & & & $\begin{array}{l}-0.215 \\
(0.091)\end{array}$ & $\begin{array}{l}-0.226 \\
(0.127)\end{array}$ \\
\hline
\end{tabular}




\begin{tabular}{|l|l|l|l|l|l|l|}
\hline & Data time span & & & & $\begin{array}{l}-0.061 \\
(0.087)\end{array}$ & $\begin{array}{l}-0.477^{* * * *} \\
(0.121)\end{array}$ \\
\hline \multirow{2}{*}{ Constant } & & $0.376^{* * *}$ & 0.308 & $0.631^{* * *}$ & $0.465^{* * * *}$ & 0.084 \\
& & $(0.093)$ & $(0.203)$ & $(0.198)$ & $(0.063)$ & $(0.176)$ \\
\hline
\end{tabular}

Notes: The variable is the after Fisher's conversion ES, the strategic change - organizational performance correlation coefficient, converted by Fisher is dependent variable. The levels of significance of $10 \%, 5 \%$ and $1 \%$ are represented by $*$,** and $* * *$ respectively.

From the Meta regression results in Table 2, $\mathrm{H} 2 \mathrm{a}$ is not confirmed in Model 1, indicating that, overall, there is no significant impact on organizational performance when the organization launches strategic changes in any directions. And the outcome of the strategic changes depends mainly on the grasp of markets and opportunities and the use of internal and external resources. $\mathrm{H} 2 \mathrm{c}$ has also not been proven, indicating that there is no significant difference in the impact of strategic change on the long-term and short-term performance of the organization. The impact of the intensity of strategic change on organizational performance in Model 1 is not significant, and the analysis of this regulatory factor is carried out in Model 5.

The regression results of enterprise ownership in model 2 show that state-owned enterprises have achieved worse organizational performance when making strategic changes $(\beta=-0.371, \mathrm{P}<0.1)$, which is consistent with the original hypothesis $\mathrm{H} 3 \mathrm{~b}$. When an enterprise belongs to a high-tech industry positively adjusts strategic changeorganizational performance relationship $(\beta=-0.254, \mathrm{P}<0.1)$, the coefficient of the traditional industry is significantly negative $(\beta=-0.279, \mathrm{P}<0.05)$. It indicates that the strategic change performance of enterprises belonging to the high-tech industry is significantly higher than that of enterprises belonging to the traditional industry, which supports the original assumption H3c. In Model 2, the impact of the two regulatory factors on organizational performance, such as enterprise size and whether the enterprise is listed or not, is not significant, and it will be analyzed in Model 5.

In Model 3, the regression results of the journal influence factors were not significant, and the original hypothesis H4a was not confirmed, indicating that the high-impact journal did not have the preference to publish strategic changes that helped improve organizational performance. The significantly negative adjustment of strategic change-organizational performance relationships in the year in which the literature is published indicates that the closer the publication time is to the literature, the less likely it is to obtain the conclusion that the strategic changeorganization performance is positively correlated. And it is inconsistent with the original assumption H4b.This may be due to the following reasons: with the development of global integration, the state pays more and more attention to the reform of enterprises. And all enterprises are catching up with the trend of the times to carry out strategic changes, not being able to adapt well to the more competitive market environment, and making more difficult profits. However, the overall correlation coefficient of strategic change-organizational performance in the integration analysis is 0.328 , that is, the overall strategy change has a positive effect on the performance of the organization.

In model 4, the adjustment factors at the research design level, the influence of data type on strategic changeorganizational performance relationship is not significant, and the original hypothesis H5a is not confirmed, indicating that there is no significant difference between the different data types and the strategic changeorganization performance relationship. The regression results of the data time span are not significant, and the analysis of the adjustment factor is continued in the all-variable model 5.

Model 5 is a full-variable model, which is consistent with the analysis results of models 1 - 4 in general, indicating that the research has a strong robustness and the research design is good. There are four regulatory factors that are not significant in the previous model but are significant in Model 5: First, the "strategic change intensity" that is not significant in model 1 significantly adjusts the strategic change-organizational performance relationship in Model $5(\beta=0.158, \mathrm{P}<0.05)$, indicating that compared to the conservative strategic changes, positive strategic

ISSN: 0010-8189 
changes could achieve better organizational performance, supporting the original assumption H2b. Second, the "enterprise scale" is not significant in model 5, in model 5, large-scale enterprises significantly positively adjust the strategic change-organizational performance relationship $\beta=0.389, \mathrm{P}<0.05)$, indicating that large-scale enterprises are more inclined to achieve better organizational performance than small and medium-sized enterprises, which supports the original assumption H3a. Third, the "listing" in model 2 significantly adjusts the strategic changeorganizational performance relationship in model $5(\beta=0.213, \mathrm{P}<0.05)$, which indicates that the listed enterprises are more inclined to obtain better organizational performance than the unlisted enterprise after carrying out the strategic change, supporting the original assumption H3d. Fourth, the "data time span" not significant in model 4 significantly negatively adjust the strategic change-organizational performance relationship $(\beta=-0.477, \mathrm{P}<0.001)$, which shows that the larger the data time span, the more likely it is to get the conclusion that the strategic change is positively related to performance, which is inconsistent with the original assumption H5b. It may be related to intense market competition and when the data time span is greater, the strategic change influence will decrease.

\section{Research Conclusions and Future Prospects}

\subsection{Research conclusions}

Through the coding and Meta integration analysis of 23 strategic change-organizational performance relationship research literature, it is found that, overall, strategic change and organizational performance showed a significantly positive correlation, with a correlation coefficient of $0.328(\mathrm{P}<0.001)$. This indicates that strategic change in the enterprise as a whole is conducive to performance improvement. The conclusion of the integrated analysis of this study further illustrates the significance of the classical strategic change theory and reflects an important theoretical value of Meta's analytical method: Meta can solve existing theoretical disputes by using the integrated quantitative research method determined by the conclusions of any single study ${ }^{35}$.

The results from Meta regression lead to the following conclusions:

(1) The type of strategic change has no significant impact on strategic change-organizational performance relationship, and positive strategic change has a better regulatory effect, indicating that no matter what type of strategic change the enterprise implements, it is key to grasp the intensity of strategic change.

(2) Compared with small and medium-sized enterprises, large-scale enterprises have better performance of strategic changes, indicating that small and medium-sized enterprises have some innate disadvantages. They have less resources, experience in strategic change, less financial capacity, the ability to deal with risks and so on. Enterprises in high-tech industries have better strategic change performance than enterprises in traditional industries. Compared with non-listed enterprises, listed enterprises achieve better strategic change performance, enterprises have more resources, better financial ability and the ability to mitigate risks, so it is possible to achieve better organizational performance. State-owned enterprises bear some inherent constraints, and their performance is worse than non-state-owned enterprises in strategic changes. The state should pay more attention to the reform of state-owned enterprises, so that state-owned enterprises also keep up with the pace of the times to create more economic and social benefits.

(3) The closer the publication of the literature, the less support is upon closer strategic change and organizational performance. As China enters a new stage of economic development, the market competition is becoming fiercer, and it is more difficult for enterprises to obtain profits than in historical periods. Neither of the high-impact or lowimpact journal has a positive preference for strategic change and organizational performance.

(4) There is no significant difference between data types in the study of strategic change-organization performance relationship, but the data time span has a significant negative adjustment effect on strategic change-organizational performance relationship.

ISSN: 0010-8189

(C) CONVERTER 2021

www.converter-magazine.info 


\subsection{Research contributions}

(1) With the Meta method, this study integrates and analyzes 23 literatures on the relationship between strategic change and organizational performance, and the results of the overall estimation after coding are positively related. It not only solves the theoretical disputes of various existing studies, the Meta analysis method also makes up for the shortcomings of qualitative and quantitative literature research in this field. And through the conclusion of the integration analysis, the effectiveness of the theory of strategic change is further confirmed, and the theory of strategic change-performance of enterprises is enriched.

(2) The reasons for heterogeneity are analyzed by Meta regression in this study, and the research method is more novel and the theoretical conclusion is also obtained. Meta integration and Meta regression analysis constitute a unique quantitative document analysis framework.

(3) About effect value processing: multiple correlation coefficients of the same dimension and different dimensions are both included in the analysis, taking into account the difference of effect values and ensuring their independence.

\subsection{Research deficiencies and future directions}

Although the current strategic change-organizational performance relationship research controversy is theoretically resolved using Meta-analysis methods in this study, there are still some shortcomings that could be improved in future studies:

(1) Although some literatures study the relationship between strategic change and organizational performance, there are no correlation coefficients in the article or the statistics of correlation coefficients can be calculated, such literature can only be excluded, resulting in the very little sample literature available for Meta-analysis.

(2) The English literature is not included in analysis, and this study focuses on the relationship between strategic change and organizational performance in the Chinese background.

(3) Although this study uses the meta integration and Meta regression method to explore the causes of the heterogeneity of strategic change-performance relationship as entirely as possible from four levels, the data shows that some regulatory factors are significant in model 1-4, not significant in the whole variable model 5 . This indicates that there are other factors affecting the relationship, which can be explored in depth in the future.

\section{References}

[1] R.B. MacKay, R. Chia, "Choice, chance, and unintended consequences in strategic change: A process understanding of the rise and fall of north coautomotive," Academy of Management Journal, vol. 56, no. 1, pp. 208-230, 2013.

[2] Y.J. Wu, "How strategic planning becomes a competitive advantage: lenovo's practice and Enlightenment," Management World,no. 4, pp. 118-129, 2007.

[3] J.R. Baum and S. Wally, "Strategic decision speed and firm performance," Strategic Manage, vol. 24, pp. 1107-1129, 2003.

[4] J.X. Wu, "The connotation, characteristics and policy implications of innovative ecosystem," Science Research, no. 1, pp. 44-51, 2014.

[5] Burns, "Management of the era of change," Yunnan University Press, 2001.

[6] H. Yu,"Empirical research on enterprise strategy orientation and technology innovation performance," Science and Science and Technology Management, no. 9, pp. 62-66, 2010.

[7] E.J. Zajac and M.S. Kraatz, “A diametric forces model of strategic change: Assessing the antecedents and consequences of restructuring in the higher education industry," Strategic Management, vol. 14, pp. 83-102, 1993.

ISSN: 0010-8189 
[8] A.S. Cui, R.J. Calantone, D.A. Griffith, "Strategic change and termination of interfirm partnerships," Strategic Management Journal, vol. 32, no. 4,pp. 402-423, 2011.

[9] D. Kelly, T.L. Amburgey, "Organizational inertia and momentum: A dynamic model of strategic change,” The Academy of Management Journal, vol. 34, no. 3, pp. 591-612, 1991.

[10] Y. Zhang, Rajagopalan N. "Once an outsider, always an outsider?” CEO Origin, Strategic Change, and Firm Performance,” Strategic Management Journal, vol. 31, no. 3, pp. 334-346, 2010.

[11] D.C. Hambrick, S.M. Schecter, "Turnaround strategies for mature industrial-product business units," Academy of Management Journal, vol. 26, no. 2, pp. 231-248, 1983.

[12] K. Xie, Y. Wu, J.H. Xiao, X.H. Liao, "Strategic risk control in organizational change-based on multicase research of enterprise internet transformation," Management World, no. 2, pp. 133-149, 2016.

[13] L.M. Gong, S.S Jiang, J. Wei,"Review of architecture theory and methodology and its implications for strategic management," Research Management, no. 5, pp. 44-53, 2014.

[14] L.M. Chen, X.Y. Wang, "Internationalization and performance improvement: research based on metaintegration and meta-regression," World Economy, no. 2, pp. 101-126, 2017.

[15] W. Du, Y.H. Si, P.C. Wen, “IT capabilities, knowledge management strategies and performance: environmental impacts," Research Management, (1):9-19, 2010.

[16] W. Li Research on the Impact of Strategic Orientation Equilibrium on Product Innovation and Business Performance . Research Management, 2015, (1):143-151.

[17] H.J. Liu. Inertia in the Evolution of Enterprise Strategy: Concept, Measurement and Contextualization . Journal of Central University of Finance and Economics, 2012, (4): 55-61.

[18] Ye. J, Marinova. D, Singh. J. Strategic change implementation and performance loss in the front lines . Journal of Marketing, 2007, 71(4):156-171.

[19] S. Chen, Q. Shu, Y. Yang The Influence of Environmental Uncertainty on the Relationship between Enterprise Strategic Change and Performance . Systems Engineering, 2012, (9):1-8.

[20] H. Sun, H. Wang Relationship between Crude Oil Price Uncertainty, Strategic Change and Firm Performance . Enterprise Economy, 2017, 36 (2):45-52.

[21] R.L. Priem. A consumer perspective on value creation . Academy Management Review, 2007, 32: 219-235.

[22] Finke, Roger. The consequences of religious competition. Supply- side explanations for religious change in L. Young (ed.) Rational Choice Theory and Religion [C] .1997. New York: Routledge.

[23] A.Y. Sun,H.C. Liu, W. Li, “Commentary on the interpretation of strategic change theory," Research Management, 2004, (6):133-140.

[24] Y.Q. Yi, X.M. He, H. Ndofor, "Dynamic Capabilities and the Speed of Strategic Change: Evidence from China . IEEE Transactions on Engineering Management, 2015, 62 (1):18-28.

[25] W.L. Zhang, D.L. Yuan, J. Zhou, "Research on the impact of strategic change on sustainable competitive advantage-evidence from panel enterprises in Taiwan, China," Modern Management Science, no. 2, pp. 15-17, 2012.

[26] C.M. Chen, H.J. Liu,"Enterprise strategic change: analysis of connotation and measurement methodology," Research Management, no. 3, pp. 67-74, 2006.

[27] C.M. Chen,"The path dependence characteristics of strategic adjustment and its transcendence," Management World, no. 6, pp. 94-101, 2002.

[28] Q.Z. Xue, H.K. Xu,"Perspective of enterprise strategic change," Economic Theory and Manager Management,no. 10, pp. 56-60, 2001.

[29] R.E. Miles, C.C. Snow, “Organizational strategy, structure and process," Stanford, CA: Stanford University Press, 2003.

[30] W. Duan, Z.M. Jin, "Research on enterprise strategic positioning from the perspective of strategic groups-the influence of strategic distance, orientation direction and strategic change on performance," Science and Technology Management, no. 3, pp. 108- 116, 2014.

[31] J.C. Wang, Y.S. Mao,"Research on the expanded business and geographical diversification strategy of chinese listed companies,” Management World, no. 2, pp. 152-153, 2006.

ISSN: 0010-8189 
[32] R. Grant, "Multinationality and performance among british manufacturing companies," Journal of International Business Studies, vol. 18, no. 3, pp. 79-89, 1987.

[33] M. Hit,R. Hoskission, H. Kim, "International diversification: effects on innovation and firm performance in product-diversified firms," Academy of Management Journal, vol. 40, no. 4, pp. 767$798,1997$.

[34] C.L. Zhang, H.Q. Zhang, "Research on the impact of strategic information technology input on enterprise performance-taking port listed companies as an example . Nanjing Social Sciences, no. 5, pp. 34-40, 2014.

[35] A. Kirca, K. Roth, S. Cavusgil, etal.,"Firm-specific assets, multinationality, and financial performance: a metaanalytic review and theoretical integration," Academy of Management Journal, vol. 54, no. 1, pp. 47-72, 2011.

\section{Attached table}

Coded results on the relationship between strategic change and organizational performance

\begin{tabular}{|c|c|c|c|c|c|c|}
\hline $\begin{array}{l}\text { Author } \\
\text { (Year) }\end{array}$ & Title & Sample & $\begin{array}{l}\text { Sample } \\
\text { size }\end{array}$ & $\begin{array}{l}\text { Correlation } \\
\text { coefficient }\end{array}$ & Effect value & $\begin{array}{l}\text { Weights } \\
(\%)\end{array}$ \\
\hline $\begin{array}{l}\text { Shen } \\
\text { bo,Xushe } \\
\text { nghua } \\
(2018)\end{array}$ & $\begin{array}{l}\text { Enterprise } \\
\text { Information Resource } \\
\text { Allocation, } \\
\text { Organizational } \\
\text { Change and } \\
\text { Enterprise } \\
\text { Performance-An } \\
\text { Empirical Study } \\
\text { Based on Structural } \\
\text { Equation Model }\end{array}$ & $\begin{array}{l}\text { Consulting companies } \\
\text { in the company's } \\
\text { annual database and } \\
\text { top } 500 \text { companies in } \\
\text { China's information } \\
\text { industry }\end{array}$ & 171 & 0.85 & 0.85 & 2.35 \\
\hline $\begin{array}{l}\text { Liu } \\
\text { Junying } \\
(2011)\end{array}$ & $\begin{array}{l}\text { Organizational } \\
\text { Learning, Strategic } \\
\text { Change, and } \\
\text { Organizational } \\
\text { Performance: An } \\
\text { Analysis Based on } \\
\text { SEM Method }\end{array}$ & $\begin{array}{l}\text { MBA students in some } \\
\text { areas of Henan } \\
\text { Province, China,senior } \\
\text { executives of } \\
\text { enterprises above } \\
\text { designated size in } \\
\text { Zhengzhou, and some } \\
\text { enterprises in Henan } \\
\text { Province }\end{array}$ & 280 & 0.785 & 0.785 & 3.88 \\
\hline $\begin{array}{l}\text { Jing } \\
\text { Xinxin, } \\
\text { Yang } \\
\text { Fuming } \\
(2018)\end{array}$ & $\begin{array}{l}\text { Does diversified } \\
\text { strategic change } \\
\text { promote or inhibit } \\
\text { corporate } \\
\text { performance?_-An } \\
\text { empirical analysis } \\
\text { based on listed real } \\
\text { estate companies in } \\
\text { China }\end{array}$ & $\begin{array}{l}\text { A-share listed real } \\
\text { estate companies }\end{array}$ & 110 & $\begin{array}{l}-0.154 \\
0.242\end{array}$ & $\begin{array}{l}-0.154 \\
0.242\end{array}$ & 3.00 \\
\hline $\begin{array}{l}\text { Wang } \\
\text { Hui, Sun } \\
\text { Hui } \\
\text { (2017) }\end{array}$ & $\begin{array}{l}\text { The relationship } \\
\text { between crude oil } \\
\text { price uncertainty, } \\
\text { strategic change and } \\
\text { corporate } \\
\text { performance }\end{array}$ & $\begin{array}{l}\text { 2001-2015 Shanghai } \\
\text { and Shenzhen A-share } \\
\text { energy listed } \\
\text { companies }\end{array}$ & 504 & 0.079 & 0.079 & 7.02 \\
\hline $\begin{array}{l}\mathrm{Hu} \\
\text { Weiwei, } \\
\text { Yao } \\
\text { Xianguo } \\
(2009)\end{array}$ & $\begin{array}{l}\text { Research on the } \\
\text { Relationship between } \\
\text { Organizational } \\
\text { Culture, Knowledge } \\
\text { Management Strategy }\end{array}$ & $\begin{array}{l}\text { The head of the } \\
\text { companies with high } \\
\text { knowledge } \\
\text { management maturity, } \\
\text { the companies in the } 《\end{array}$ & 125 & 0.685 & 0.685 & 1.71 \\
\hline
\end{tabular}

ISSN: 0010-8189 


\begin{tabular}{|c|c|c|c|c|c|c|}
\hline & and Performance & $\begin{array}{l}\text { China Business } \\
\text { Directory》 }\end{array}$ & & & & \\
\hline $\begin{array}{l}\text { Peng } \\
\text { Can, } \\
\text { Yang } \\
\text { Ling } \\
(2009)\end{array}$ & $\begin{array}{l}\text { Research on the } \\
\text { relationship between } \\
\text { technological ability, } \\
\text { innovation strategy } \\
\text { and innovation } \\
\text { performance }\end{array}$ & $\begin{array}{l}\text { High-tech enterprises } \\
\text { in the } 《 \text { China Business } \\
\text { Directory》 }\end{array}$ & 197 & 0.63 & 0.63 & 2.72 \\
\hline $\begin{array}{l}\text { Fu Jing, } \\
\text { Zhu } \\
\text { Guilong } \\
\text { (2014) }\end{array}$ & $\begin{array}{l}\text { Research on the } \\
\text { Influence of } \\
\text { Knowledge-Based } \\
\text { Strategy and } \\
\text { Absorptive Capacity } \\
\text { on Enterprise's } \\
\text { Innovation } \\
\text { Performance Output }\end{array}$ & $\begin{array}{l}\text { Enterprises of } \\
\text { Technology Center in } \\
\text { Guangdong Province, } \\
\text { China }\end{array}$ & 343 & 0.61 & 0.61 & 4.77 \\
\hline $\begin{array}{l}\text { Jin Wei, } \\
\text { Chen } \\
\text { Song } \\
(2015)\end{array}$ & $\begin{array}{l}\text { The Influence of } \\
\text { Knowledge Source } \\
\text { Strategy and } \\
\text { Dynamic Capability } \\
\text { on Exploratory } \\
\text { Innovation } \\
\text { Performance- } \\
\text { Based on the } \\
\text { Empirical Study of } \\
\text { Knowledge-intensive } \\
\text { Service Enterprises }\end{array}$ & $\begin{array}{l}\text { Knowledge intensive } \\
\text { enterprises }\end{array}$ & 214 & $\begin{array}{l}0.552 \\
0.543\end{array}$ & 0.548 & 2.96 \\
\hline $\begin{array}{l}\text { Xue Lei } \\
\text { et al } \\
(2011)\end{array}$ & $\begin{array}{l}\text { The Impact of } \\
\text { Strategic Orientation } \\
\text { on the Product } \\
\text { Innovation } \\
\text { Performance of } \\
\text { Chinese } \\
\text { Enterprises_A A } \\
\text { Comparison of High- } \\
\text { Tech Industry-Non- } \\
\text { High-Tech Industry } \\
\text { Enterprises }\end{array}$ & $\begin{array}{l}\text { enterprises of high-tech } \\
\text { industry and non-high- } \\
\text { tech industry }\end{array}$ & $\begin{array}{l}272 \\
229\end{array}$ & $\begin{array}{l}0.42 \\
0.49 \\
0.25 \\
0.66\end{array}$ & $\begin{array}{l}0.420 .49 \\
0.250 .66\end{array}$ & 13.88 \\
\hline $\begin{array}{l}\text { Liu Chao } \\
\text { et al } \\
(2013)\end{array}$ & $\begin{array}{l}\text { Organizational } \\
\text { creativity and } \\
\text { organizational } \\
\text { innovation } \\
\text { performance: } \\
\text { strategically oriented } \\
\text { regulatory effects }\end{array}$ & $\begin{array}{l}\text { randomly selected } \\
\text { enterprises in } \\
\text { Guangdong Province, } \\
\text { Shandong Province, } \\
\text { Henan Province, } \\
\text { Shaanxi Province, } \\
\text { China }\end{array}$ & 269 & $\begin{array}{l}0.32 \\
0.35\end{array}$ & 0.320 .35 & 7.46 \\
\hline $\begin{array}{l}\text { Li Wei } \\
(2015)\end{array}$ & $\begin{array}{l}\text { Research on the } \\
\text { Impact of Strategic } \\
\text { Orientation } \\
\text { Equilibrium on } \\
\text { Product Innovation } \\
\text { and Business } \\
\text { Performance }\end{array}$ & $\begin{array}{l}\text { Randomly sample } \\
\text { technology companies } \\
\text { in four technology } \\
\text { parks in Chongqing } \\
\text { Liangjiang New } \\
\text { District and Tianjin } \\
\text { Binhai New Area, } \\
\text { China }\end{array}$ & 228 & $\begin{array}{l}0.426 \\
0.374\end{array}$ & 0.4260 .374 & 6.3 \\
\hline $\begin{array}{l}\text { Yang Lin } \\
\text { et al } \\
(2016)\end{array}$ & $\begin{array}{l}\text { Research on the } \\
\text { relationship between } \\
\text { company's } \\
\text { entrepreneurial }\end{array}$ & $\begin{array}{l}\text { SME board listed } \\
\text { company before the } \\
\text { end of } 2005\end{array}$ & 88 & $\begin{array}{l}0.208 \\
0.134\end{array}$ & 0.2080 .134 & 2.38 \\
\hline
\end{tabular}

ISSN: 0010-8189 


\begin{tabular}{|c|c|c|c|c|c|c|}
\hline & $\begin{array}{l}\text { strategy orientation, } \\
\text { senior management } \\
\text { team's vertical } \\
\text { difference and } \\
\text { entrepreneurial } \\
\text { performance }\end{array}$ & & & & & \\
\hline $\begin{array}{l}\mathrm{Li} \text { Yi, Si } \\
\text { Youhe } \\
(2009)\end{array}$ & $\begin{array}{l}\text { The Relationship } \\
\text { between Knowledge } \\
\text { Management } \\
\text { Strategy, Innovation } \\
\text { and Performance- } \\
\text { Based on Analysis of } \\
\text { Enterprise Strategy }\end{array}$ & $\begin{array}{l}\text { EMBA, MBA and the } \\
\text { students of business } \\
\text { management short } \\
\text { courses in Shanghai, } \\
\text { Anhui Province and } \\
\text { Chongqing, companies } \\
\text { in Beijing, Zhejiang } \\
\text { Province, Fujian } \\
\text { Province and } \\
\text { Guangdong Province, } \\
\text { China }\end{array}$ & 397 & $\begin{array}{l}0.346 \\
0.251\end{array}$ & 0.299 & 5.52 \\
\hline $\begin{array}{l}\text { Chen } \\
\text { Shou et } \\
\text { al } \\
(2012)\end{array}$ & $\begin{array}{l}\text { The Influence of } \\
\text { Environmental } \\
\text { Uncertainty on the } \\
\text { Relationship between } \\
\text { Enterprise Strategic } \\
\text { Change and } \\
\text { Performance }\end{array}$ & $\begin{array}{l}\text { Manufacturing } \\
\text { enterprises listed on the } \\
\text { Shanghai and } \\
\text { Shenzhen A shares } \\
\text { before December } 31 \text {, } \\
2002\end{array}$ & 216 & 0.41 & 0.41 & 2.99 \\
\hline $\begin{array}{l}\text { Yu Hao } \\
(2010)\end{array}$ & $\begin{array}{l}\text { Empirical Research } \\
\text { on Enterprise } \\
\text { Strategy Orientation } \\
\text { and Technology } \\
\text { Innovation } \\
\text { Performance }\end{array}$ & $\begin{array}{l}\text { Biotechnology } \\
\text { Enterprise in Zhejiang } \\
\text { Province, China }\end{array}$ & 310 & -0.32 & -0.32 & 4.30 \\
\hline $\begin{array}{l}\text { Zhou } \\
\text { Jiebin } \\
(2018)\end{array}$ & $\begin{array}{l}\text { Research on the } \\
\text { relationship between } \\
\text { strategic decision } \\
\text { makers' management } \\
\text { cognition, corporate } \\
\text { strategic change and } \\
\text { corporate } \\
\text { performance }\end{array}$ & $\begin{array}{l}\text { 2012-2014 A-share } \\
\text { listed manufacturing } \\
\text { companies }\end{array}$ & 197 & 0.122 & 0.122 & 2.72 \\
\hline $\begin{array}{l}\text { Liao } \\
\text { Lina } \\
(2015)\end{array}$ & $\begin{array}{l}\text { Research on the } \\
\text { relationship between } \\
\text { chairman and general } \\
\text { manager's tenure, } \\
\text { strategic change and } \\
\text { corporate } \\
\text { performance change }\end{array}$ & $\begin{array}{l}\text { Enterprises in Shanghai } \\
\text { and Shenzhen listed } \\
\text { companies whose } \\
\text { performance has } \\
\text { declined for three } \\
\text { consecutive years }\end{array}$ & 201 & 0.521 & 0.521 & 2.78 \\
\hline $\begin{array}{l}\text { Shao } \\
\text { Jianbing, } \\
\text { Li Wei } \\
(2017)\end{array}$ & $\begin{array}{l}\text { Executive } \\
\text { Compensation Gap, } \\
\text { Strategic Change and } \\
\text { Corporate } \\
\text { Performance: The } \\
\text { Regulating Role of } \\
\text { Management Power }\end{array}$ & $\begin{array}{l}\text { The top } 20 \text { funds of the } \\
\text { fund management } \\
\text { institution's public fund } \\
\text { scale at the end of } \\
\text { September } 2015\end{array}$ & 538 & 0.161 & 0.161 & 7.50 \\
\hline $\begin{array}{l}\text { Zhao } \\
\text { Lixiang, } \\
\text { Zhang } \\
\text { Wenyuan } \\
(2015)\end{array}$ & $\begin{array}{l}\text { Industry Monopoly } \\
\text { Power, Strategic } \\
\text { Change and } \\
\text { Enterprise } \\
\text { Performance: Based }\end{array}$ & $\begin{array}{l}\text { Mature companies of } \\
\text { 2008-2012 Shanghai } \\
\text { and Shenzhen A-share } \\
\text { manufacturing listed }\end{array}$ & 133 & 0.114 & 0.114 & 1.82 \\
\hline
\end{tabular}

ISSN: 0010-8189 
CONVERTER MAGAZINE

Volume 2021, No. 5

\begin{tabular}{|c|c|c|c|c|c|c|}
\hline & $\begin{array}{l}\text { on the Perspective of } \\
\text { Enterprise Life Cycle }\end{array}$ & & & & & \\
\hline $\begin{array}{l}\text { Wu } \\
\text { Xiaoyun, } \\
\text { Li Hui } \\
(2015)\end{array}$ & $\begin{array}{l}\text { Research on the } \\
\text { Influence Mechanism } \\
\text { of Bank Strategic } \\
\text { Capability on } \\
\text { Performance Based } \\
\text { on Competitive } \\
\text { Strategy Type }\end{array}$ & $\begin{array}{l}\text { Commercial banks } \\
\text { participating in market } \\
\text { competition }\end{array}$ & 107 & $\begin{array}{l}0.4470 .380 \\
0.585\end{array}$ & 0.471 & 1.46 \\
\hline $\begin{array}{l}\text { Liu } \\
\text { Haichao, } \\
\text { Li Wei } \\
(2009)\end{array}$ & $\begin{array}{l}\text { The Structural } \\
\text { Relationship among } \\
\text { Competitive Pressure, } \\
\text { Strategic Change and } \\
\text { Firm Performance- } \\
\text { - A Study of China's } \\
\text { Transition Economy }\end{array}$ & $\begin{array}{l}\text { Researched companies } \\
\text { in Shanxi Province, } \\
\text { Shaanxi Province, } \\
\text { Henan Province, } \\
\text { Sichuan Province, } \\
\text { Liaoning Province, } \\
\text { Shanghai, Shenzhen, } \\
\text { and Shandong } \\
\text { Province, China }\end{array}$ & 585 & $\begin{array}{l}0.252 \\
0.257 \\
0.206 \\
0.265\end{array}$ & 0.245 & 8.16 \\
\hline $\begin{array}{l}\text { Cao } \\
\text { Hongjun } \\
\text { et al } \\
(2016)\end{array}$ & $\begin{array}{l}\text { The Non-linear } \\
\text { Influence of Resource } \\
\text { Allocation Strategy } \\
\text { Change on Firm } \\
\text { Performance- } \\
\text { Based on the } \\
\text { Research Perspective } \\
\text { of Executive Team } \\
\text { Fault Line }\end{array}$ & $\begin{array}{l}\text { High-tech enterprises } \\
\text { in some sub-sectors of } \\
\text { the Shanghai and } \\
\text { Shenzhen stock } \\
\text { markets listed before } \\
\text { the end of } 2010\end{array}$ & 240 & -0.142 & -0.142 & 3.32 \\
\hline $\begin{array}{l}\text { Kong } \\
\text { Ningning } \\
\text { et al } \\
\text { (2010) }\end{array}$ & $\begin{array}{l}\text { Research on the } \\
\text { Relationship between } \\
\text { China's High-tech } \\
\text { Enterprise Strategy, } \\
\text { Capital Structure and } \\
\text { Performance }\end{array}$ & $\begin{array}{l}\text { 2006-2008,R \& D data } \\
\text { disclosure relatively } \\
\text { more pharmaceutical } \\
\text { bio-products and } \\
\text { information technology } \\
\text { industry listed } \\
\text { companies of high- } \\
\text { tech industries in } \\
\text { Shanghai and } \\
\text { Shenzhen, China }\end{array}$ & 75 & 0.415 & 0.415 & 1.01 \\
\hline
\end{tabular}

